Keywords: Cotard syndrome, Neuroimaging neurophysiology, Neuropsychology.

\title{
An overview of the neurological correlates of Cotard syndrome
}

\author{
Swamy N C Kudlur MRCPsych* \\ Sanju George MRCPsych ${ }^{* *}$ \\ Mathew Jaimon MS***
}

* Specialist Registrar in Psychiatry, Small Heath Health Centre, 42 Chapman Road, Small Heath, Birmingham

** Specialist Registrar in Psychiatry, Queen Elizabeth Psychiatric Hospital, Edgbaston, Birmingham

*** Department of ENT, District General Hospital, Eastbourne

UNITED KINGDOM

\begin{abstract}
Background and objectives: Considerable etiologic ambiguity surrounds Cotard syndrome and a range of psychodynamic, existential and biological theories have been proposed to explain its etiopathogenesis. Despite the often-noted neurological abnormalities on examination and assessment in Cotard syndrome, an in-depth evaluation is lacking. In this paper, we provide an overview of the neurological (neurostructural, neurophysiological and neuropsychological) correlates of Cotard syndrome and discuss the implications of our findings from an etiological and clinical perspective.

Methods: We searched electronic databases and key journals using the appropriate search terms. All reported cases of Cotard syndrome with neurological investigations published in English were included in the review. The two authors independently reviewed the full text of over 100 papers and selected the papers for inclusion in the final review.

Results: Various organic conditions such as typhoid fever, temporal lobe epilepsy, brain tumours and brain injuries have been reported in association with Cotard syndrome. The most commonly reported neurological abnormalities in these patients include structural brain changes (bilateral cerebral atrophy, dilated lateral ventricles), functional brain changes (hypoperfusion in the frontal and parietal cortices) and neuropsychological abnormalities (impaired face recognition).

Conclusions: In summary, although not all, some cases of Cotard syndrome are associated with structural and functional brain dysfunction. From a clinical perspective, it is crucial to maintain a low threshold for suspicion of organicity in cases of this uncommon psychiatric syndrome, and thereafter to consider appropriate neurological investigations.
\end{abstract}


Jules Cotard, a French physician, in 1880, described the case of a 43-year-old woman who reported that she had "no brain, nerves, chest, or entrails and was just skin and bone -neither God nor the Devil existed- she was eternal and would live forever' ${ }^{1}$. He called it 'delire de negation', and this was to posthumously bear his name and later be popularised as 'Cotard syndrome'. Although, the central symptom of Cotard syndrome is the nihilistic delusion, it can present with varying degrees of severity, ranging from mild forms where patients express feelings of despair, through to more severe forms where patients deny their own existence and or the existence of the world itself.

Considerable nosological ambiguity surrounds Cotard syndrome. Berrios \& Luque, in an extensive review of the conceptual history of Cotard syndrome, concluded that Jules Cotard probably viewed it as a subtype of melancholia (anxious melancholia) ${ }^{2}$. However, others view it as a syndrome (associated with a range of conditions such as depression, psychosis, organic conditions and so on), while some others consider it a distinct entity. In an attempt to further understand the phenomenology of Cotard syndrome, Berrios \& Luque, using an exploratory factor analysis of 100 cases of Cotard syndrome reported in literature, extracted three factors: psychotic depression, Cotard type I and Cotard type II $^{3}$. The psychotic depression patients mostly had depression and few nihilistic delusions. Cotard type I patients on the other hand, had only the nihilistic delusions (pure Cotard syndrome) and few depressive symptoms, whereas Cotard type II patients were a mixed group with depression, anxiety and auditory hallucinations.

It is worth emphasizing that Cotard Syndrome is best conceptualised as being on a spectrum (complete / incomplete): the complete form in which nihilistic delusions are clearly present and the incomplete forms which are often combinations of depressed mood, delusions of guilt and hypochondriasis, and hallucinations. Also the nihilistic delusion itself could vary in its degree of severity - from severe (patient denies his own and the world's existence) to mild (patient feels that he is loosing his reasoning and feelings). Yamada et al. ${ }^{4}$ attempted to trace the onset and longitudinal progression of Cotard syndrome from a phenomenological perspective and identified 3 distinct stages: the germination stage (prodromal period associated with depression and hypochondriacal symptoms), the blooming stage (full blown development of the syndrome with delusions of negation) and the chronic stage (chronic depressive type or chronic delusional type). They equated the above 3 stages to the earlier classification of Cotard Syndrome by Berrios \& Luque as follows: the germination stage corresponds to psychotic depression, the blooming stage to Cotard type 2 and the chronic stage to Cotard type 1.

Nosological ambiguity often does not lend itself well to etiological clarity. So much so that, a range of diverse etiological explanations has been proposed to explain the genesis of Cotard syndrome: psychodynamic, existential, sociological and biological $^{1}$. Notwithstanding the isolated case reports/case series describing some of the neurological abnormalities in Cotard syndrome, a detailed evaluation of the neurological aspects of the syndrome is lacking. In this paper, we attempt to provide an overview of the neurological (neurostructural, neurophysiological and neuropsychological) correlates of Cotard syndrome and discuss the implications of our findings. 


\section{Methodology}

We conducted an extensive literature review and searched the following electronic, bibliographic databases: Medline (1951 to date), Embase (1974 to date) and Psychinfo (1887 to date). Our search used the terms Cotard, Cotard syndrome, severe depression, Cotard delusion and nihilistic delusion. References of studies thus identified were searched for further studies and we also hand searched key journals and books. Our exclusion criteria included studies published in non-English languages, cases of Cotard syndrome with no reported neurological investigations and cases of Cotard syndrome coexisting with delusional misidentification syndromes. In the first phase, the two authors (S.K \& S.G) independently reviewed the full text of over 100 papers reporting cases of Cotard syndrome, and excluded those papers that did not meet the inclusion criteria. In phase II, all included papers were analysed by the first author (S.K) and the relevant information was extracted, based on a pre-designed proforma. See Table I for organic conditions associated with Cotard syndrome and Table II for the detailed neurodiagnostic findings identified in literature.
In Table II (in the $3^{\text {rd }}$ column) we give a brief description of the psychopathology/ phenomenology of each case included in this paper (where the information was available). As is evident from the findings presented here, there is no universally accepted definition of Cotard syndrome and hence it is best viewed as a 'spectrum of completeness/incompleteness of the syndrome'. For the purposes of this paper, we adopted a broad definition of Cotard syndrome and were guided by Berrios and Luque's conceptualisation - 'there is little support for the view that delire des negations should refer only to the delusion of being dead. Such a view is likely to waste information and hamper any possibility of finding out whether the symptom-cluster involved has any stable brain representation.

\section{Results}

\section{Structural neuroimaging (CT/MRI) studies}

Thirty-five cases of Cotard syndrome with structural neuroimaging findings were identified in the literature (see Table II for details).

Table I

Organic conditions associated with Cotard syndrome.

Condition

Cited description

Typhoid fever
Cerebral infarction
Brain tumours (Astrocytoma)
Temporal lobe epilepsy
Traumatic brain injury
Migraine
Laurence-Moon-Bardet-Biedl syndrome
A-V malformations
Multiple sclerosis
Parkinson's disease

Campbell, Volow \& Cavenar (20)

Drake (6)

Drake (6)

Bhatia (8)

Drake (6)

Young, Leafhead (22)

Drake (6)

Young et al. (10)

Bhatia (14)

Lerner et al. (33)

Gardner-Thorpe (9)

Gardner-Thorpe (9)

Factor, Molho (34) 


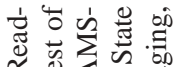

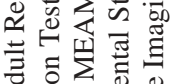
《造造

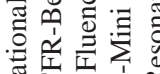

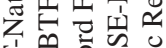

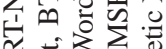

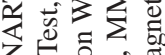

ิิ

氜

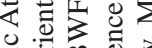

当品总

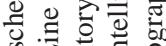
齿

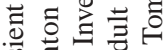

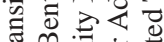

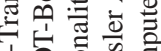

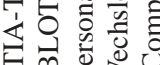

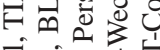

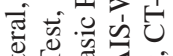
焉茨 긍을

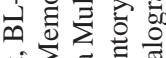

武

도웡

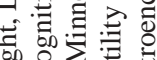

tot $\sum_{0} \sum_{1}$

또옹 $\frac{0}{11}$

สే 히일

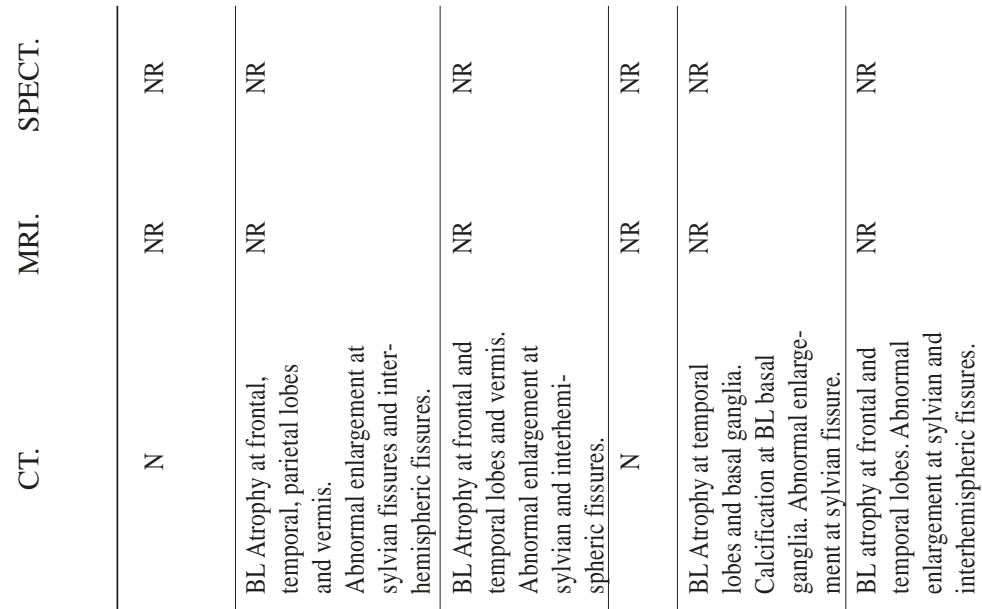

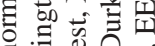

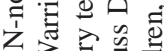

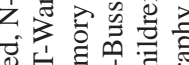

$\stackrel{d}{g}$

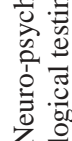

这离它

品品总

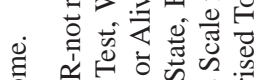

Z . : ت

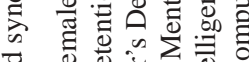

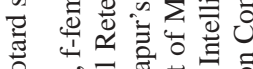

픈 ज्ञ ज्ञ

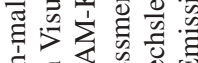

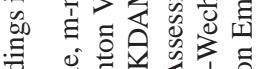

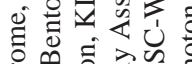

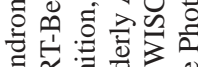

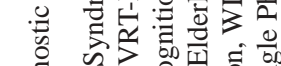

$=$ 要

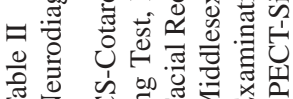

式

过

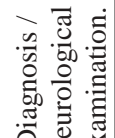

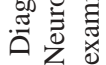

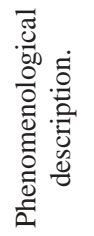

$\operatorname{sid}_{\infty}^{\infty}$

$<\infty$

氖

部

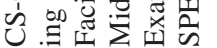

$\dot{0}$ 


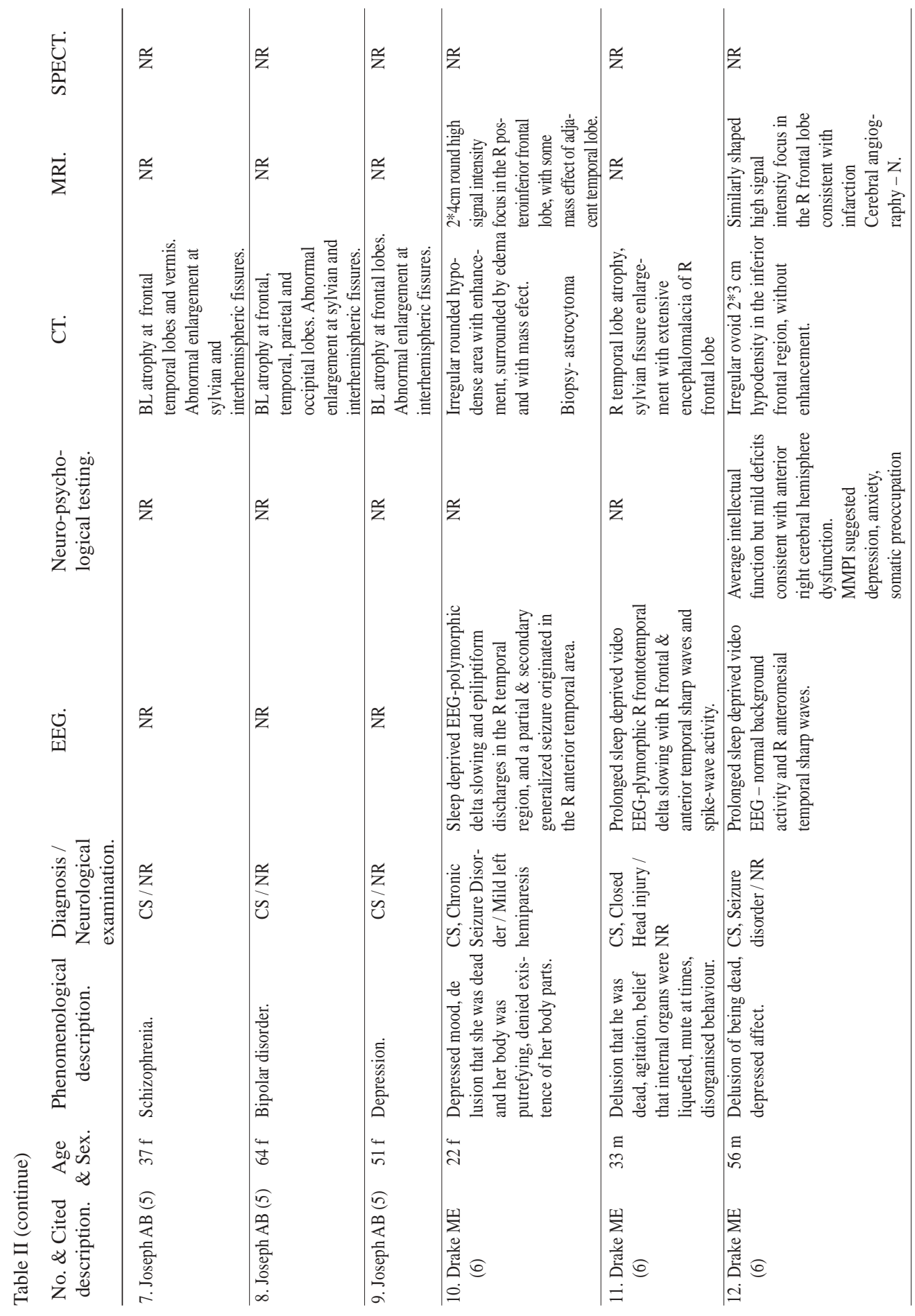




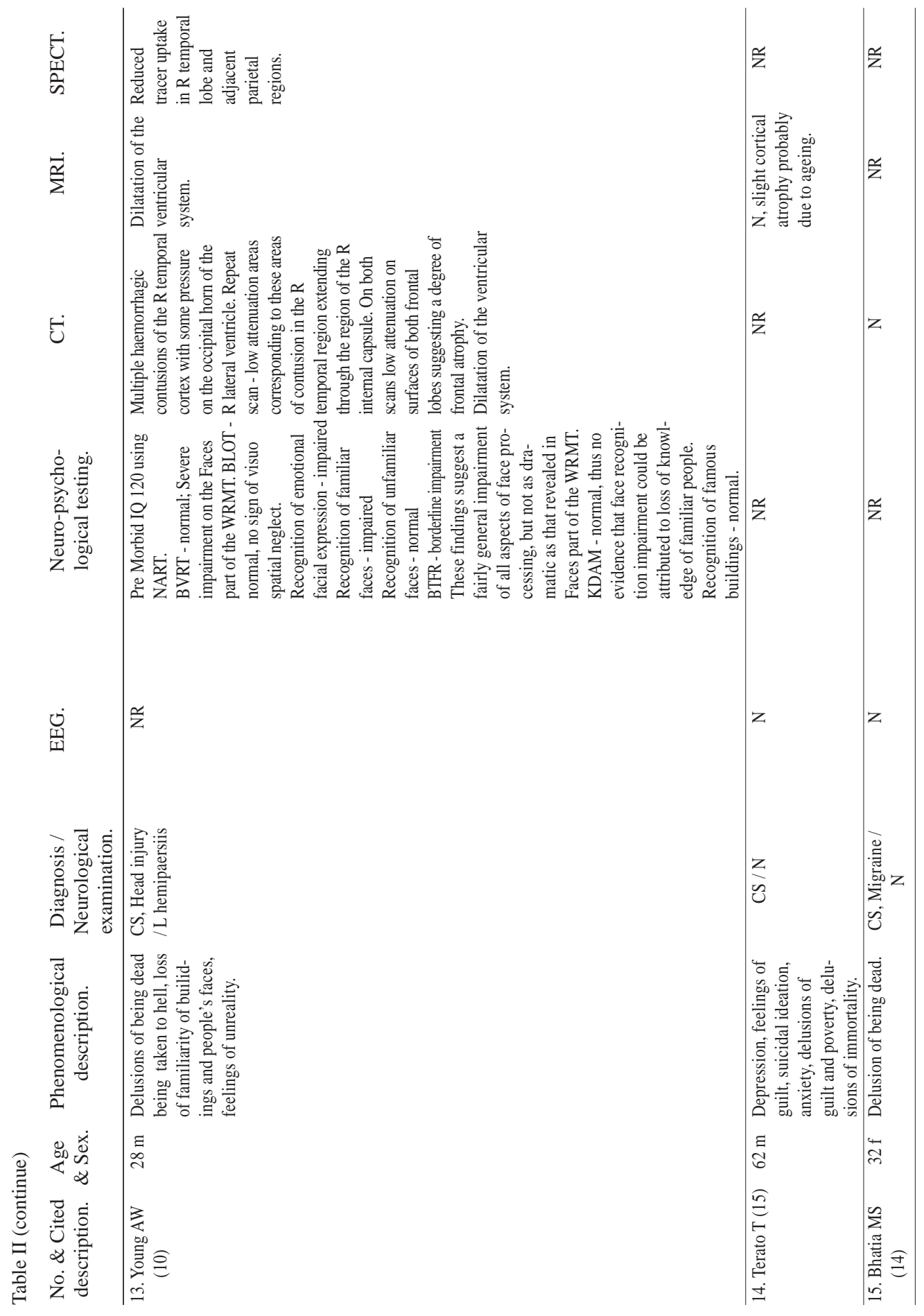




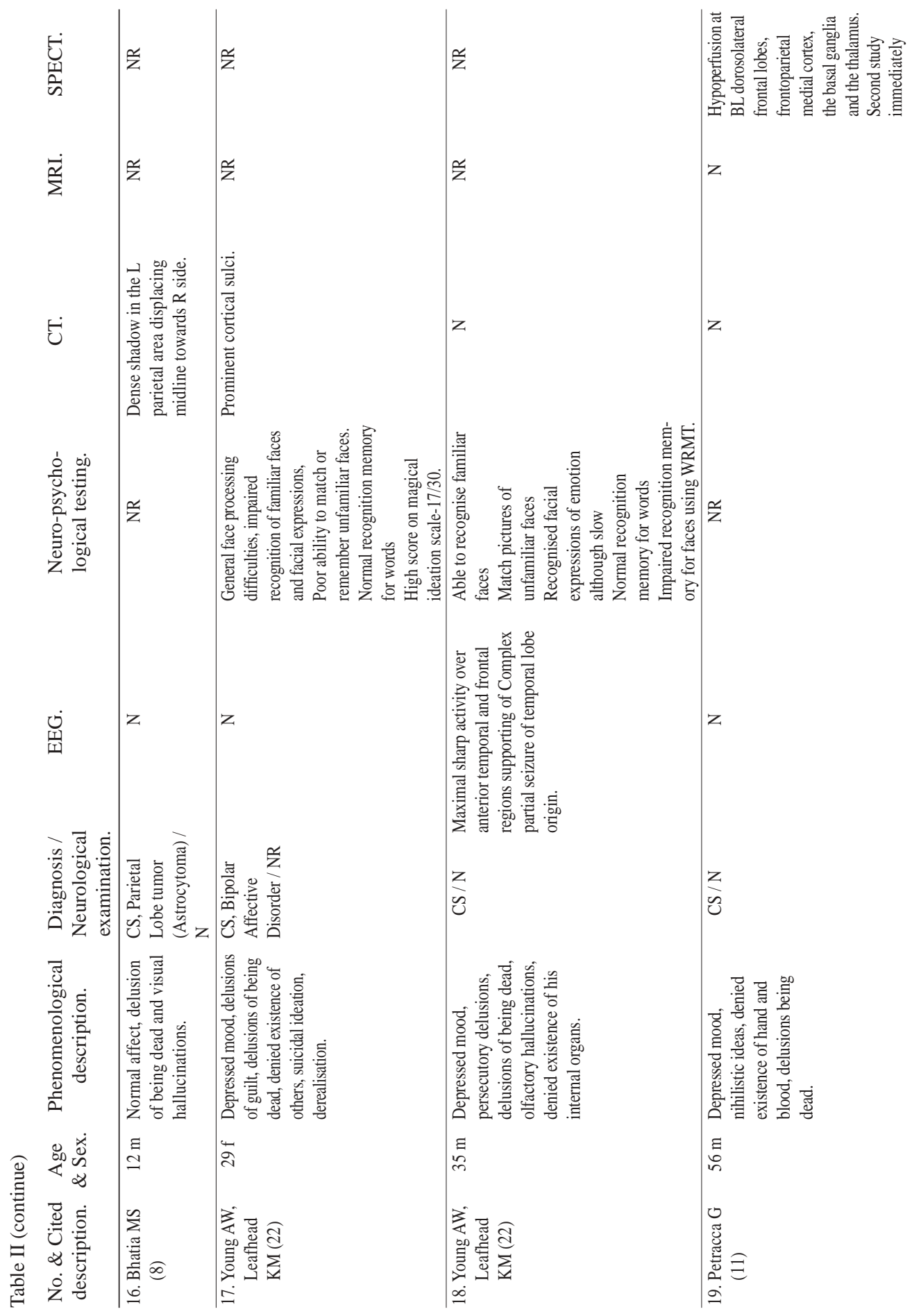




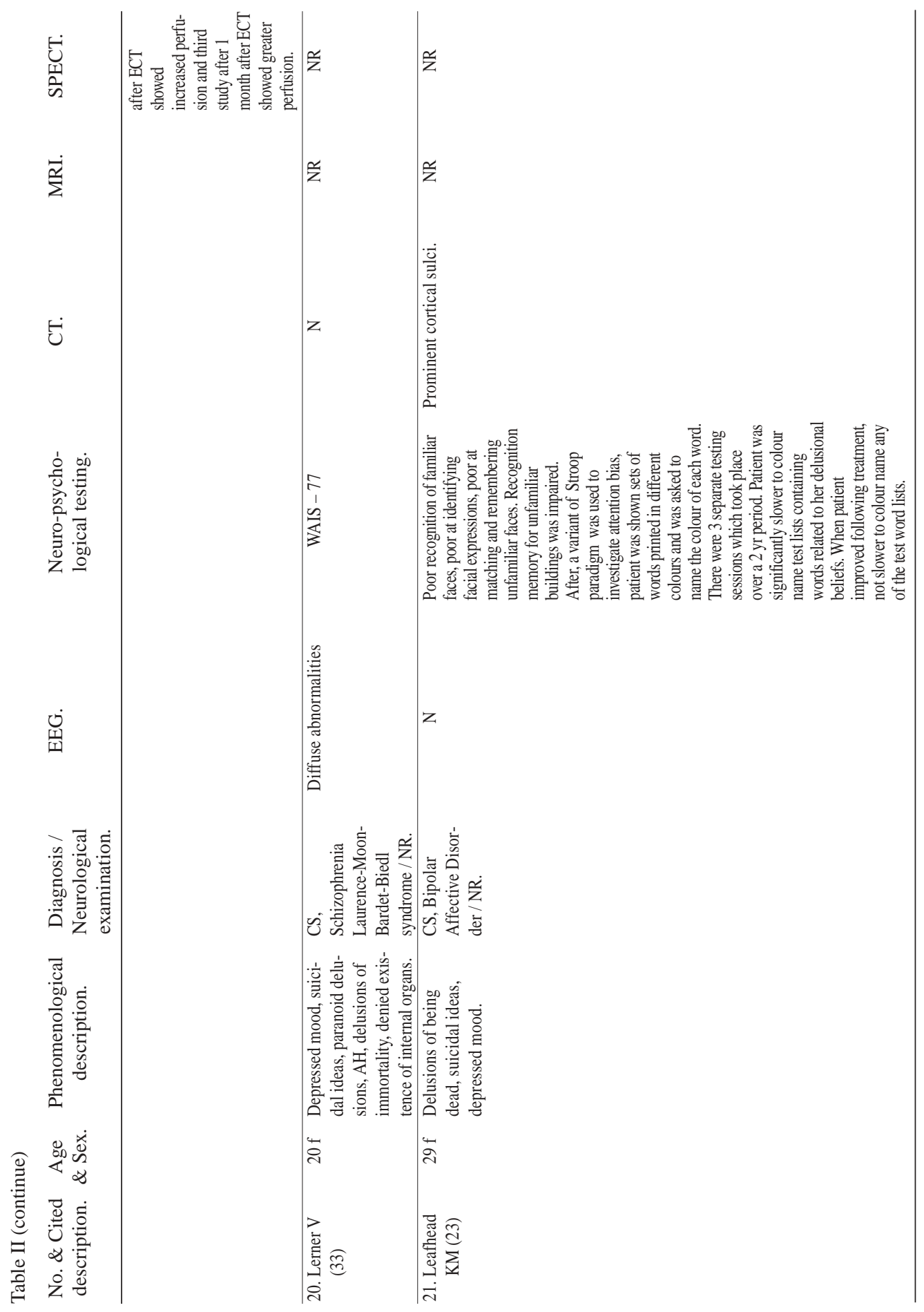




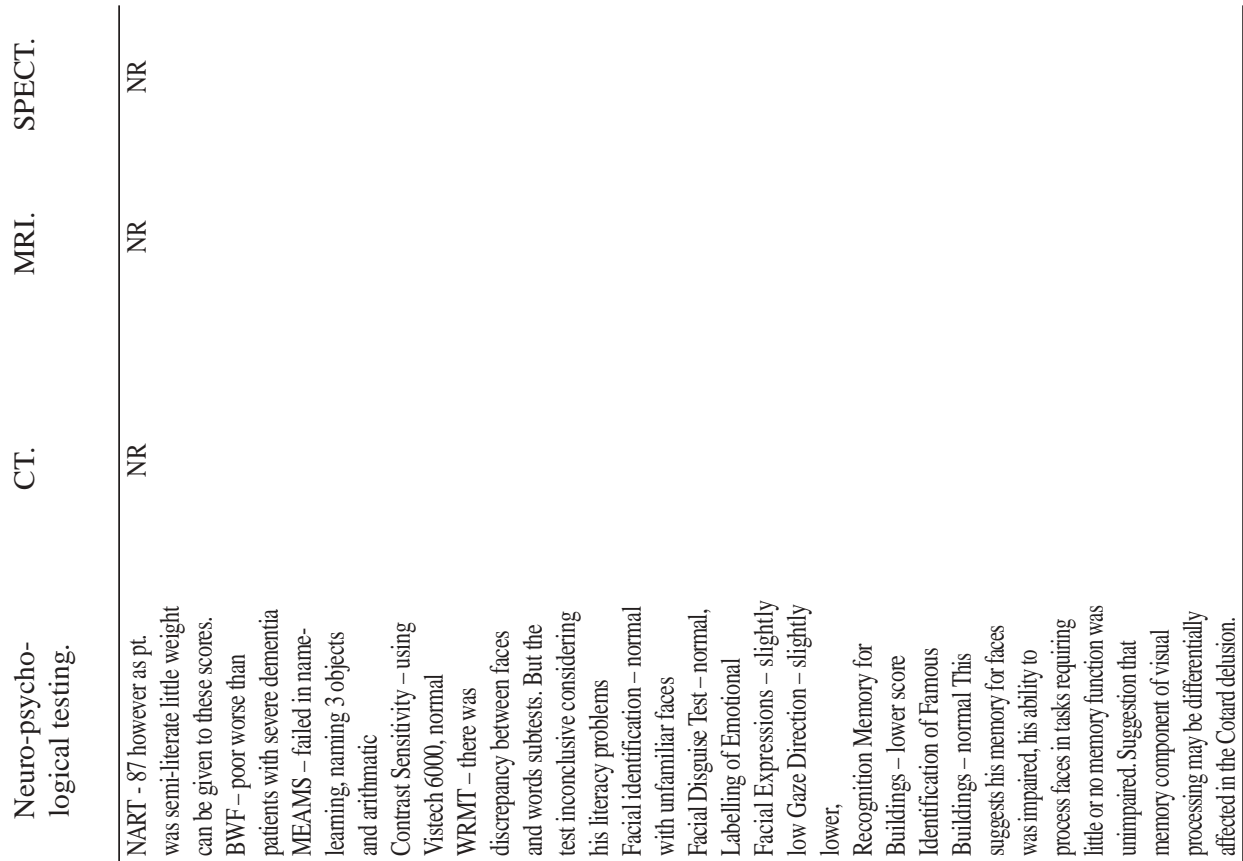

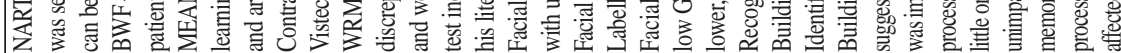

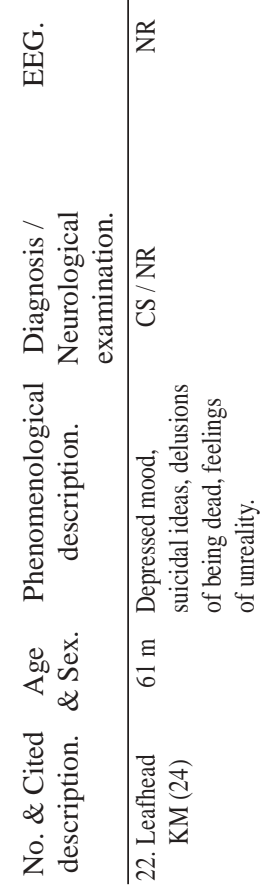




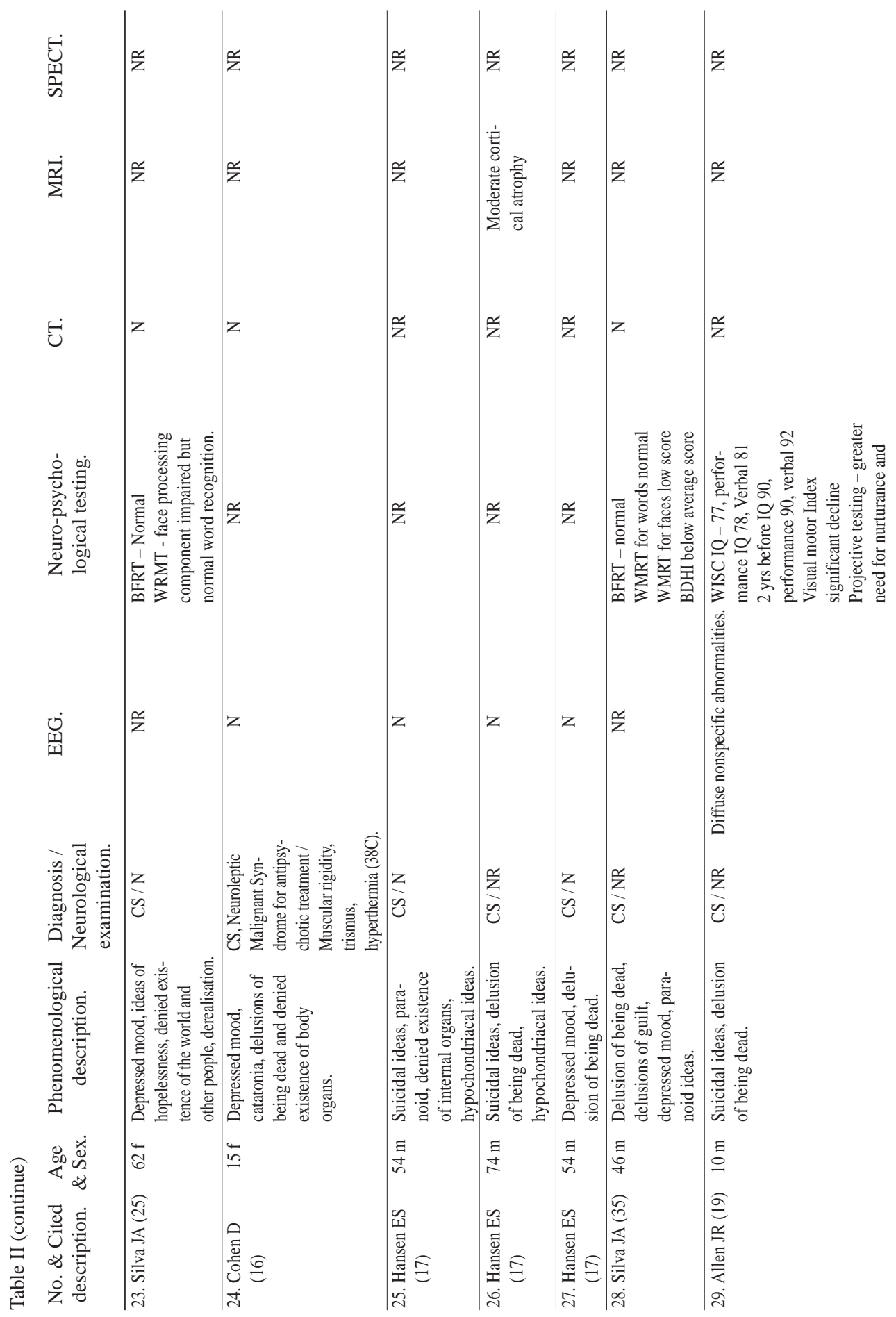




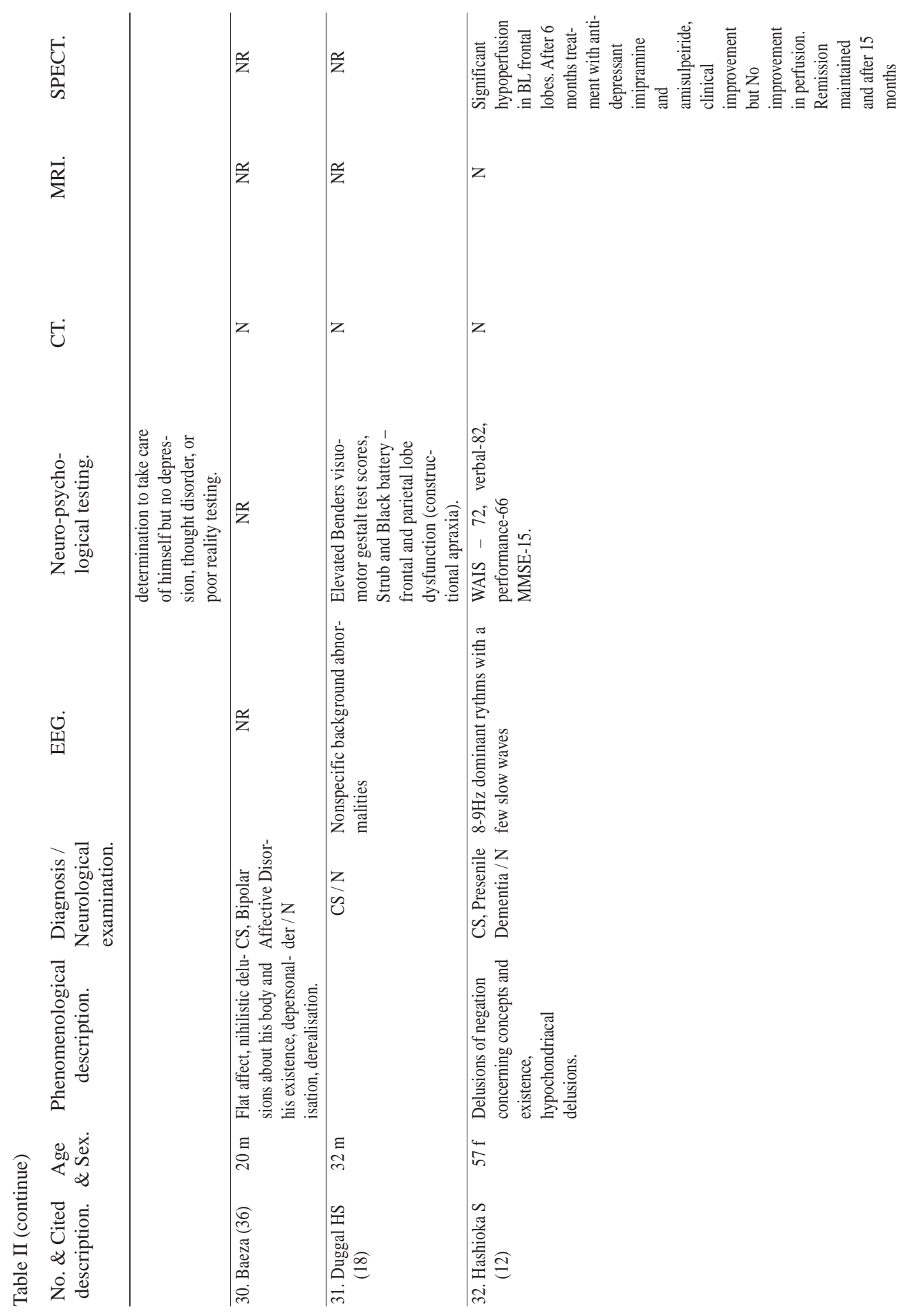


110 SWAMY N C ET AL.

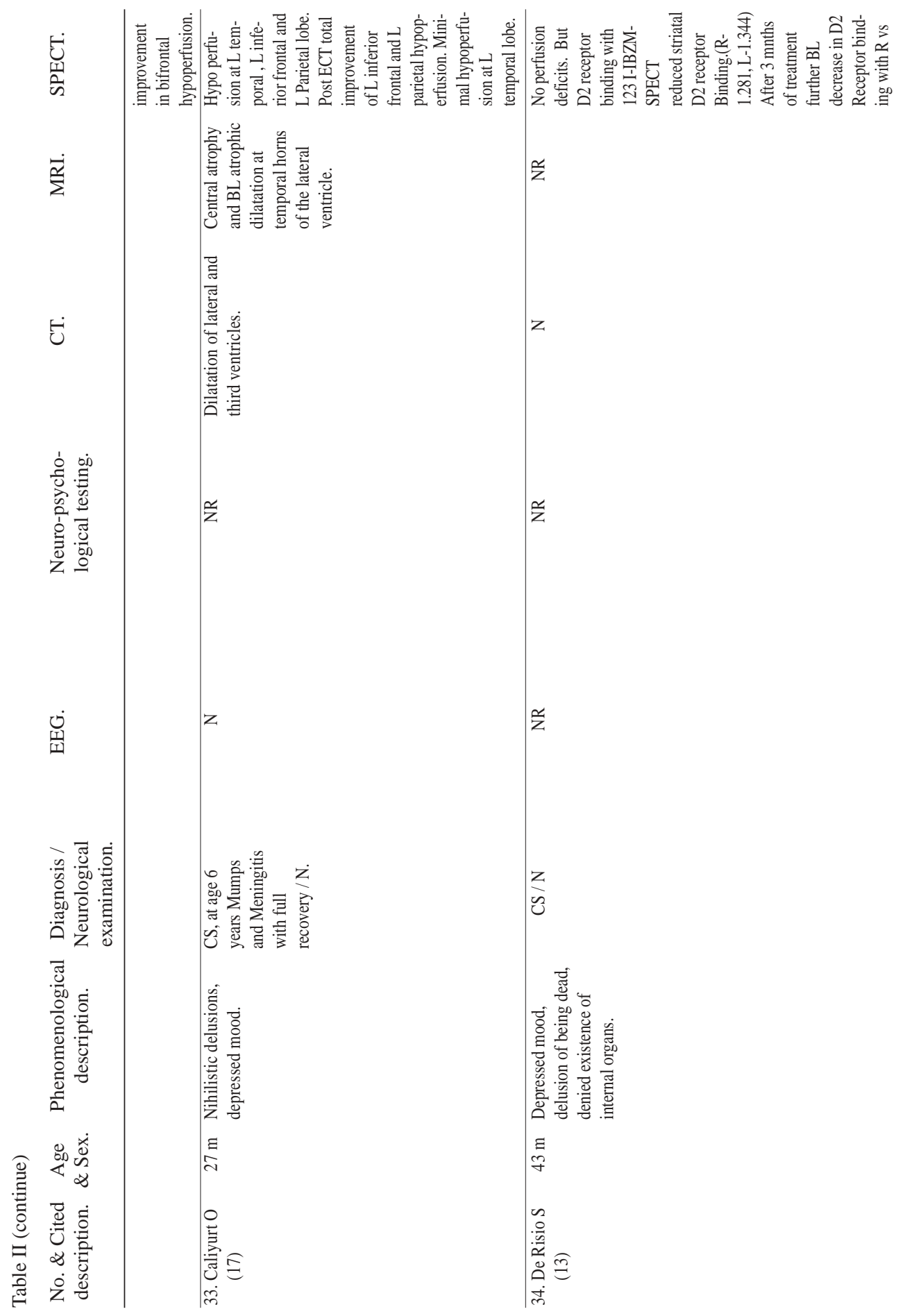




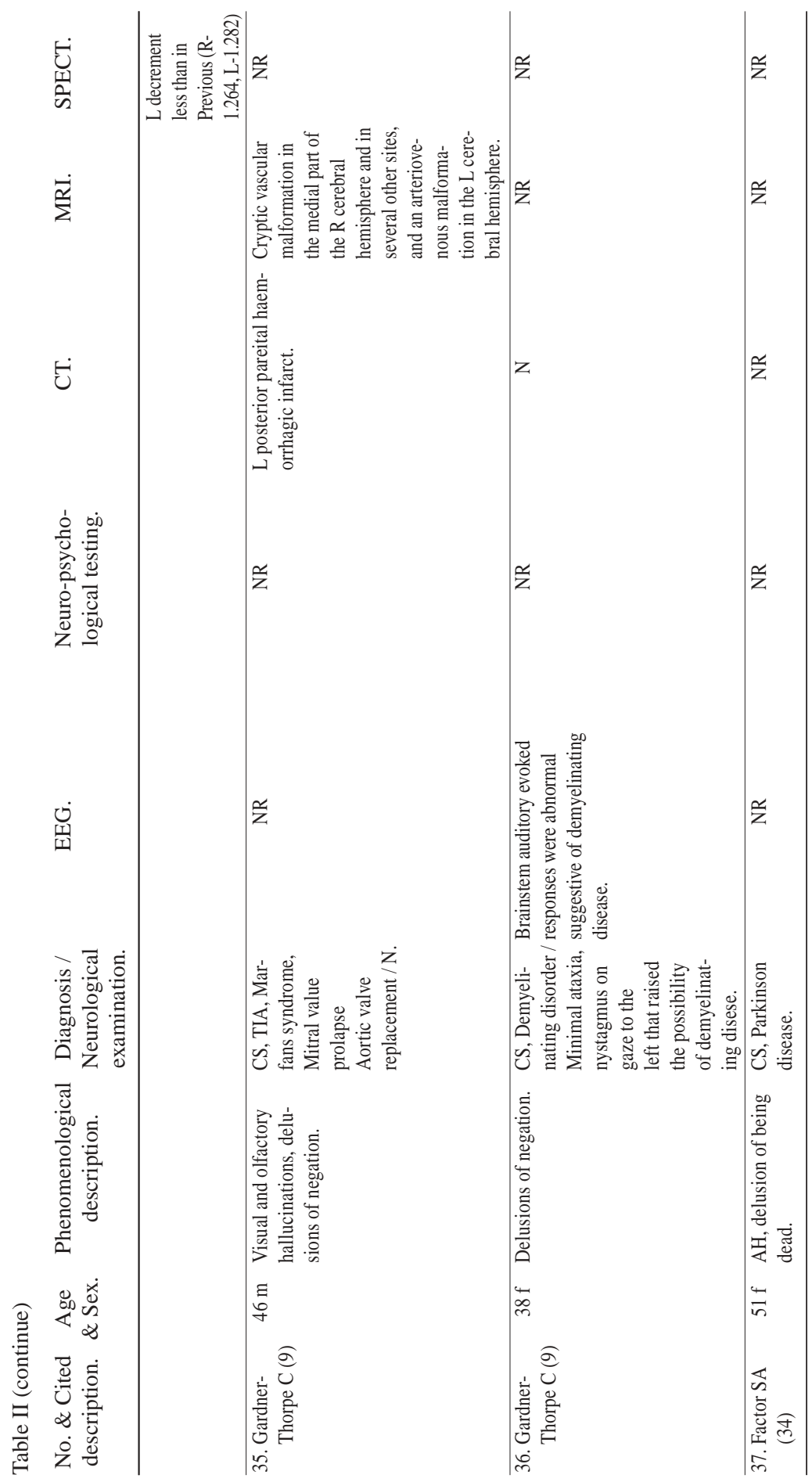


Joseph compared the CT scans of eight patients who had Cotard syndrome with eight controls (without Cotard syndrome but matched for the psychiatric diagnosis) and noted significant differences between the two groups ${ }^{5}$. The most common abnormalities in patients with Cotard syndrome were bilateral cerebral atrophy, sylvian and interhemispheric fissure enlargement, and dilatation of lateral ventricles. There were no differences in basal ganglia abnormalities and frontal, temporal or parietal atrophy. Drake described three patients with right fronto-temporal structural lesions and temporal lobe epilepsy, who all also had Cotard syndrome 6 . MRI scan in his first patient revealed a $2 \times 4 \mathrm{~cm}$ round high signal intensity focus in the right postero inferior frontal lobe. In his second patient, with post head injury seizures and Cotard syndrome, CT scan showed right temporal lobe atrophy and sylvian fissure enlargement, and in the third patient, CT revealed a $2 \times 3$ $\mathrm{cm}$ hypo density in the inferior frontal region. Other structural abnormalities found in association with Cotard syndrome include dilation of the third and lateral ventricles ${ }^{7}$, left parietal lobe lesions ${ }^{8,9}$ and haemorrhagic contusion of the right temporal cortex ${ }^{10}$. Notwithstanding the above listed structural abnormalities, it is important to note that many more cases of Cotard syndrome with normal CT/MRI findings have been reported (see Table I).

\section{SPECT studies}

Limited research in this area precludes valid inferences being drawn. Only five cases of Cotard syndrome with SPECT findings were identified. Two cases report blood flow abnormalities to the brain that resolved after treatment with $\mathrm{ECT}^{7,11}$. In the first patient (Cotard syndrome with depres- sion), SPECT showed bilateral hypo-perfusion in the dorsolateral frontal lobes, fronto parietal medial cortex, basal ganglia and thalamus.

Subsequent SPECT scan studies immediately after and one month after a course of ECT demonstrated progressively greater perfusion in the above-mentioned region ${ }^{11}$. In the second patient (Cotard syndrome with schizophreniform disorder), hypo perfusion in the left temporal, left inferior frontal and left parietal lobe, improved completely, post-ECT, except for persisting minimal left temporal lobe hypo perfusion ${ }^{7}$. Hashioka noted no improvement in perfusion on SPECT, six months after pharmacological treatment, despite clinical remission. However, SPECT scan in the same patient done 15 months later revealed improvements in the bifrontal hypo perfusion ${ }^{12}$. In the only study that evaluated D2 receptor binding using SPECT, De Risio noted reduced striatal D2 receptor binding (right vs. left percentage decrement $-4.92 \%$ ), with visual inspection confirming left > right uptake ${ }^{13}$. Three months after treatment with clozapine, further bilateral decrease in D2 receptor binding, with right vs. left decrement less than in the previous SPECT was noted.

\section{Neurophysiological studies}

Eighteen reports of neurophysiological investigations in cases of Cotard syndrome were noted (see Table II). Most revealed no EEG abnormalities ${ }^{7,8,11,14-18}$ whereas others revealed diffuse non-specific abnormalities $^{19}$ and abnormalities suggestive of the underlying organic condition such as typhoid fever or multiple sclerosis $9,19,20$, Drake studied three patients with TLE and Cotard syndrome and noted the following abnormalities on sleep-deprived EEG: poly- 
morphic delta slowing and epileptiform discharges in the right temporal region (case 1), polymorphic right frontotemporal delta slowing with right frontal and anterior temporal sharp waves and spike wave activity (case 2) and right anteromesial temporal sharp waves (case 3$)^{6}$. Joseph used BEAM (brain electrical activity mapping) in a 34year-old woman with Cotard syndrome to find generalized electrophysiological abnormalities with a right temporal predominance $^{21}$.

\section{Neuropsychological studies}

These studies in Cotard syndrome have most commonly focussed on various tests of intelligence and tests of facial recognition and memory. In all, 12 case studies were identified but only 4 had mentioned the neuropsychological findings in detail ${ }^{10,22-24}$.

Neuropsychological testing of a 28-yearold man with Cotard syndrome revealed severe impairment on the faces part of the Warrington Recognition Memory Test, impairment of recognition of emotional facial expression and recognition of familiar faces and borderline impairment on the Benton test of facial recognition. These findings suggest a fairly general impairment of all aspects of face processing, with no evidence that face recognition impairment could be attributed to loss of knowledge of familiar people. Leafhead studied a 61-yearold man with Cotard syndrome, using a neuropsychological test battery and found impaired recognition memory for words, faces, and buildings and for identification of faces $^{24}$. She also demonstrated normal recognition of emotional facial expressions and facial disguise. Similar findings (impairments in recognition of familiar faces and facial expressions) have also been noted by others $22,23,25,26$.

\section{Discussion}

This study had three important limitations: language bias, publication bias and the small sample size. First, language bias. Exclusion of papers published in non-English languages might have limited the total number of cases available for inclusion. Second, publication bias. It is to be noted that not all cases of Cotard syndrome seen by psychiatrists in their day-to-day practice are likely to be written up and published. It is more likely that cases of Cotard syndrome with positive neurological findings will be published. Hence, the inferences and generalizations that can be drawn from a largely skewed sample (only those cases with abnormal neurological findings) regarding the underlying neurological correlates of Cotard syndrome in general, are limited. Third, despite encouraging trends, research into the neuropsychological and neuroimaging aspects of Cotard syndrome is limited, as evidenced from the limited number of case reports eligible for inclusion in the study. A larger sample would have probably enhanced the validity of our conclusions.

Most of the above-discussed cases of Cotard syndrome had an associated, underlying organic condition such as TLE, head injury, or brain tumour (see Table I). So, it could be argued that the neurological abnormalities (neuropsychological or neurostructural) noted are a manifestation of the underlying organic condition and not of Cotard syndrome itself. Simply demonstrating an association/coexistence between Cotard syndrome and neurological abnormalities does not prove causality. Hence, it is not possible to draw valid inferences about the aetiology of Cotard syndrome from such studies. However, they still point to some possible underlying neurological 
substrates that might play a role in the etiopathogenesis of Cotard syndrome. In summary, although not all, some cases of Cotard syndrome are associated with structural and functional brain dysfunctions. From a clinical perspective, it is crucial to maintain a low threshold for suspicion of organicity in cases of this uncommon psychiatric syndrome (Cotard syndrome), and thereafter to consider appropriate neurological investigations.

Although not consistent, most CT/MRI studies of Cotard syndrome noted abnormalities in the non-dominant frontal, temporal and occasionally the parietal lobes. Drake noted that Cotard syndrome is most probably due to an irritative focus in the right frontal and temporal lobes ${ }^{6}$. This is in keeping with previous research linking Cotard syndrome with non-dominant cerebral hemisphere abnormalities ${ }^{21}$. There is also considerable evidence linking the origins of content-specific delusions to the right hemisphere, especially the frontal lobe ${ }^{27,28}$. The importance of right temporal lobe dysfunction superimposed on widespread cerebral atrophy in the aetiology of Cotard syndrome was further highlighted by Joseph and O'Leary ${ }^{5}$, who demonstrated overall brain atrophy in 8 patients as compared to controls. They also found interhemispheric fissure enlargement in 6 of their 8 cases and hypothesized that it might be secondary to medial frontal lobe atrophy.

SPECT scan studies too have identified abnormalities in the frontal region of the brain in Cotard syndrome, often reversible with treatment ${ }^{11}$. They noted decreased blood flow in the medial fronto parietal and frontal dorsolateral cortex. However, this study did not rule out whether these perfusion abnormalities were due to the underlying depression or the Cotard syndrome itself. Authors argue that the medial fron- toparietal and thalamic perfusion abnormalities produce a degraded body schema, which in the context of depression, leads to the development of Cotard syndrome.

So far, most of the neuropsychological findings in Cotard syndrome point towards face processing impairments as the central mechanism in its aetiology. Young and Leafhead proposed a neuropsychological model of Cotard syndrome, incorporating components of face-processing impairments, abnormal feelings, derealization and depressed mood ${ }^{22}$. They viewed Cotard syndrome as 'a depressed person's attempt to account for abnormal perceptual experiences'. The overlap of Cotard syndrome with misidentification syndromes, and Capgras syndrome in particular, has been extensively studied ${ }^{25,26,29}$. As Cotard syndrome has been noted to coexist and even sequentially follow Capgras syndrome $e^{5,30}$, and given the commonalities in the neuropsychological (face-processing impairments) and neurostructural (non-dominant cerebral hemisphere lesions) abnormalities, it has been suggested that they may share common pathophysiological mechanisms ${ }^{21,30}$. A detailed discussion of the neuropsychological models of Capgras syndrome is beyond the remit of this paper see references ${ }^{31,32}$.

In 1995, concluding a review of the conceptual history of Cotard syndrome, Berrios and Luque remarked "we suggest that before speculation starts on any neurobiological basis for the delire des negations, efforts should be made to remap its clinical features and basic clinical correlations' ${ }^{2}$. Ten years on, our review has hopefully shed some light on the recent advances in the field of neurobiology of Cotard syndrome and will encourage enthusiastic clinicians and researchers to revisit this area. Much more research is needed before definitive 
conclusions about the neurological substrates of Cotard syndrome can be drawn.

\section{References}

1. Enoch D, Ball H. Cotard's syndrome. In: Enoch D, Ball H, editors. Uncommon Pyschiatric Syndromes, (4 ${ }^{\text {th }}$ edition). London: Arnold Publishers; 2001. p.155-178.

2. Berrios GE, Luque R. Cotard's delusion or syndrome? A conceptual history. Compr Psychiatry 1995; 36(3): 218-223.

3. Berrios GE, Luque R. Cotard's syndrome: analysis of 100 cases. Acta Psychiatr Scand 1995; 91: 185-188.

4. Yamada K, Katsuragi S, Fujii I. A case study of Cotard's syndrome: stages and diagnosis. Acta Psychiatr Scand 1999; 100: 396-399.

5. Joseph AB, O'Leary DH. Brain Atrophy and Interhemispheric Fissure Enlargement in Cotard's Syndrome. J Clin Psychiatry 1986; 47(10): 518-520.

6. Drake ME. Cotard's syndrome and temporal lobe epilepsy. Psychiatr J Univ Ottawa 1988; 13(1): 36-39.

7. Caliyurt O, Vardar E, Tuglu C. Cotard's syndrome with schizophreniform disorder can be successfully treated with electroconvulsive therapy: case report. Rev Psychiatr Neurosci 2004; 29(2): 138-141.

8. Bhatia, MS. Cotard's syndrome in parietal lobe tumour. Indian Paediatr 1993; 30: 1019-1021.

9. Gardner-Thorpe C, Pearn J. The cotard syndrome. Report of two patients: with a review of the extended spectrum of 'delire des negations'. Eur J Neurol 2004; 11: 563-566.

10. Young AW, Robertson IH, Hellawell DJ, Pauw KW, Pentland B. Cotard delusion after brain injury. Psychol Med 1992; 22: 799-804.

11. Petracca G, Migliorelli R, Vazquez S, Starkstein SE. SPECT Findings Before and After ECT in a Patient with Major Depression and Cotard's Syndrome. Journal Neuropsychiatry 1995; 7(4): 505-507.

12. Hashioka S, Monji A, Sasaki M, Yoshida I, Baba K, Tashiro N. A Patient With Cotard Syndrome Who Showed an Improvement in Single Photon Emission Computed Tomography Findings After Successful Treatment With Antidepressants. Clin Neuropharmacol 2002; 25(5): 276-279.

13. De Risio S, De Rossi G, Sarchiapone M, Camardese G, Carli V, Cuomo C, et al. A case of Cotard syndrome: 123I-IBZM SPECT imaging of striatal D2 receptor binding. Psychiatry Res Neuroimaging 2004; 130: 109-112.
14. Bhatia MS, Agrawal P, Malik SC. Cotard's Syndrome in Migraine. Indian J Med Sci 1993; 47(6): 152-153.

15. Terao T, Fujino A, Egashira K, Abe K. LithiumAntidepressant Combination in the Treatment of Depressive Cotard's Syndrome. Ann of Clin Psychiatry 1992; 4: 227-230.

16. Cohen D, Cottias C, Basquin M. Cotard's syndrome in a 15-year-old girl. Acta Psychiatr Scand 1997; 95: 164-165.

17. Hansen ES, Bolwig TG. Cotard syndrome: An important manifestation of melancholia. Nord J Psychiatry 1998; 52: 459-464.

18. Duggal HS, Jagadheesan K, Haque Nizamie S. Biological basis and staging of Cotard's syndrome. Eur Psychiatry 2002; 17: 108-109.

19. Allen JR, Pfefferbaum B, Hammond D, Speed L. A disturbed child's use of a public event: cotard's syndrome in a ten-year-old. Psychiatry 2000; 63(2): 208-213.

20. Campbell S, Volow MR, Cavenar JO. Cotard's syndrome and the psychiatric manifestations of typhoid fever. Am J Psychiatry 1981; 138(10): 1377-1378.

21. Joseph AB. Cotard's Syndrome in a Patient With Coexistent Capgras' Syndrome, Syndrome of Subjective Doubles, and Palinopsia. J Clin Psychiatry 1986; 47(12): 605-606.

22. Young AW, Leafhead KM. Betwixt life and death: case studies of the cotard delusion. In: Halligan PW, Marshall JC, editors. Method in Madness: Case Studies in Cognitive Neuropsychiatry. Hove, UK: Psychology Press; 1996. p. 147-171.

23. Leafhead KM, Young AW, Szulecka TK. Delusions Demand Attention. Cognitive Neuropsychiatry 1996; 1(1): 5 16.

24. Leafhead KM, Kopelman MD. Face Memory Impairment in the Cotard Delusion. In: Parkin AJ, editor. Case studies in the Neuropsychology of Memory. Hove, UK: Psychology press; 1997. p. 165-177.

25. Silva JA, Leong GB. The Relation of Cotard's Syndrome to Delusional Misidentification. Isr J Psychiatry Relat Sci 1996; 33(3): 188-193.

26. Young AW, Leafhead KM, Szulecka TK. The Capgras and Cotard Delusions. Psychopathology 1994; 27: 226-231.

27. Levine DN, Grek A. The anatomic basis of delusions after right cerebral infarction. Neurology 1984; 34: 577-582.

28. Malloy PF, Richardson ED. The Frontal Lobes and Content-Specific Delusions. J Neuropsychiatry Clin Neurosci 1994; 6: 455-466.

29. Silva JA, Leong GB. Cotard's Syndrome as a Misidentification Process. The Psychiatric Forum 1993; 30-32. 
30. Wright S, Young AW, Hellawell DJ. Sequential Cotard and Capgras delusions. Br J Clin Psychol 1993; 32: 345-349.

31. Edelstyn NMJ, Oyebode F. A Review of the Phenomenology and Cognitive Neuropsychological Origins of the Capgras syndrome. Int J Geriatr Psychiatry 1999; 14: 48-59.

32. Ellis HD, Young AW. Accounting for delusional misidentifications. Br J Psychiatry 1990; 157: 239-248.

33. Lerner V, Bergman J, Greenberg D, Bar-El Y. Laurence-Moon-Bardet-Biedl syndrome in combination with cotard syndrome. Case report. Isr J Psychiatry Relat Sci 1995; 32(4): 291-294.

34. Factor SA, Molho ES. Threatening auditory hallucinations and cotard syndrome in Parkinson disease. Clin Neuropharmacol 2004; 27(5): 205-207.

35. Silva JA, Leong GB, Weinstock R, Gonzales CL. A case of Cotard's Syndrome Associated with Self-Starvation. J Forensic Sci 2000; 45(1): 188-190.

36. Baeza I, Salv J, Bernardo M. Cotard's Syndrome in a Young Male Bipolar Patient. J Neuropsychiatry Clin Neurosci 2000; 12: 117-120.

\section{Selected non-English references}

(Although non-English articles were excluded from our review, here is a selection of some such papers for the interested reader).

- Bourgeois M. Le syndrome de Cotard aujourd'hui. Ann Med Psychol (Paris) 1969; 127: 534-544.

- Cotard J. Etudes sur les Maladies Cerebrales et Mentales. Paria Bailliera, 1891.

- Degiovanni A, Faure M, Leveque JP, Gaillard P. Le syndrome de Cotard chez le jeune: a propos de deux observations. Ann Med Psychol (Paris) 1987; 145: 874-876.
- Failla E, Coppola CF, Sinisi C. A proposito della syndrome di Cotard. Rassegna Neuropsichiatria 1962; 16: 361380 .

- Halfon O, Mouren-Simeoni MC, Dugas M. Le syndrome de Cotard chez l'adolescent. Ann Med Psychol (Paris) 1985; 143: 876-879.

- Henne M, Tourel M. A propos des etats mixtes. Une observation de syndrome de Cotard maniaque. Ann Med Psychol (Paris) 1961; 119: 318-324.

- Loudet, O, Martinez, L. Sobre la psicogenesis y el valor pronostico del syndrome de Cotard. Arch Argentinos Neurol 1993; 1: 1-12.

- Majeron M, Finavera L. La syndrome di Cotard: aspetto atipico della melancholia involutiva. Minerva Med 1975; 66: 4269-4272.

- Tissot F. Delire des negations termine par guerison. Considerations sur l'hypochondrie et la melancolie. Ann Med Psychol (Paris) 1921; 79: 321-328.

- Vitello A. Melancolia di Cotard con paranoidismo schizoide. Rassegna Studi Psichiatrici 1970; 59: 195-210.

- Vitetta M. Su un caso di syndrome di Cotard. Rassegna Studi Psichiatrici 1962; 51: 39-55.

Address for correspondence: Dr Swamy N C Kudlur MRCPsych Specialist Registrar in Psychiatry Small Heath Health Centre 42 Chapman Road Small Heath, Birmingham UNITED KINGDOM - B10 0PG Phone: 00441213015047 Fax: 00441215005853

e-mail: kudlurs@yahoo.com 